\title{
DYNAMICS OF SERUM POTASSIUM CHANGE DURING ACUTE RESPIRATORY ALKALOSIS
}

\author{
M.G. SANChEz AND D.C. FinLAYSON
}

THE USE OF MECHANical VentILATION in the operating room is commonplace in modern anaesthesia and often leads to varying degrees of hyperventilation and respiratory alkalosis that may cause significant alterations in the metabolic state of the patient. ${ }^{1-7}$ One of the most significant changes which occurs is a fall in the serum potassium which may be seen even in the presence of normal body potassium.

During respiratory alkalosis, potassium ions carrying a positive charge, move from the plasma and extracellular fluid and cross the cell membrane into the cell to replace positively charged hydrogen ions that are moving into the extracellular fluid. ${ }^{8,9.10}$ The resulting hypokalaemia may produce significant disturbances in the function of myocardial cells and may be important in patients who have an unstable myocardium because of coronary insufficiency or valvular disease and who may also be receiving digitalis and/or diuretics. ${ }^{11-17.19}$ There has been little written in the recent literature to suggest awareness of the degree to which the serum potassium may fall with hyperventilation. ${ }^{18}$ Therefore this study was undertaken to evaluate the rapidity with which these changes occur during artificial ventilation in ordinary clinical situations in daily practice.

\section{Materials ANd Methods}

Seventeen patients aged 18-43 were studied. All were free of cardiopulmonary, metabolic or renal disease and had been receiving no medication for a minimum of two weeks before admission to hospital. The surgical procedures consisted of head and neck operations, mostly tympanoplasties and mastoidectomies: these operations were chosen for minimal tissue trauma and insignificant blood loss.

Anaesthesia lasted a minimum of two hours and a maximum of two and a half hours. During this period an average of $750 \mathrm{ml}$ of five per cent dextrose in water was infused intravenously. The

M.G. Sanchez, M.D., F.R.C.P.(C), D.C. Finlayson, M.D., F.R.C.P.(C), Department of Anaesthesia, St. Michael's Hospital, University of Toronto, Toronto, Canada.

Canad. Anaesth. Soc. J., vol 25, no 6, November 1978 anaesthetic technique was essentially the same for all patients. Premedication consisted of morphine sulphate $10-15 \mathrm{mg}$ and perphenazine $2.5-5 \mathrm{mg}$ given intramuscularly one hour before operation. Anaesthesia was induced with thiopentone and intubation of the trachea was facilitated by the injection of succinylcholine $1 \mathrm{mg} / \mathrm{kg}$. Anaesthesia was maintained with nitrous oxide and oxygen and supplemented with curare and a narcotic as necessary. Morphine, meperidine and fentanyl were used at random in equipotent doses for analgesia.

The assessment of alveolar ventilation was achieved using an infrared carbon dioxide analyzer (Godart) to determine end-tidal $\mathrm{PCO}_{2}$. $\mathrm{Pa}_{\mathrm{CO}_{2}}$ levels were confirmed by arterial blood gas analysis using a Corning 175 automatic $\mathrm{pH} /$ blood gas system calibrated with known concentrations of carbon dioxide. Blood potassium and chloride were measured by a Technicon auto-analyzer 2 . Coefficient of variation was 1.8 per cent for $\mathrm{K}^{+}$ and 1.1 per cent for $\mathrm{Cl}^{-}$.

Monitoring during operation consisted of a continuous display of the electrocardiogram and the pulse contour. The blood pressure was taken at frequent intervals by the standard Riva Rocei technique and the temperature was monitored using an oesophageal thermistor.

The metabolic and acid base status were evaluated every 30 minutes from blood samples obtained from a teflon radial arterial cannula inserted percutaneously after induction of anaesthesia, but before the operation. Informed consent was obtained from the patients.

The study was divided into three phases. In the pre-operative phase the patients were allowed to breathe spontaneously before any curare had been given. There was no operation during this period and spontaneous respiration was allowed after recovery from succinylcholine, to avoid the elevated values of serum potassium which may occur following the administration of that drug. Evidence would suggest that these changes tend to disappear within ten to fifteen minutes. ${ }^{2.18}$ The operative phase lasted for 90 minutes. In this period the lungs were hyperventilated to a mean $\mathrm{Pa}_{\mathrm{CO}_{2}}$ of $3.46 \mathrm{kPa}$ (26 torr). The post-operative and last phase, emergence from anaesthesia, 495 


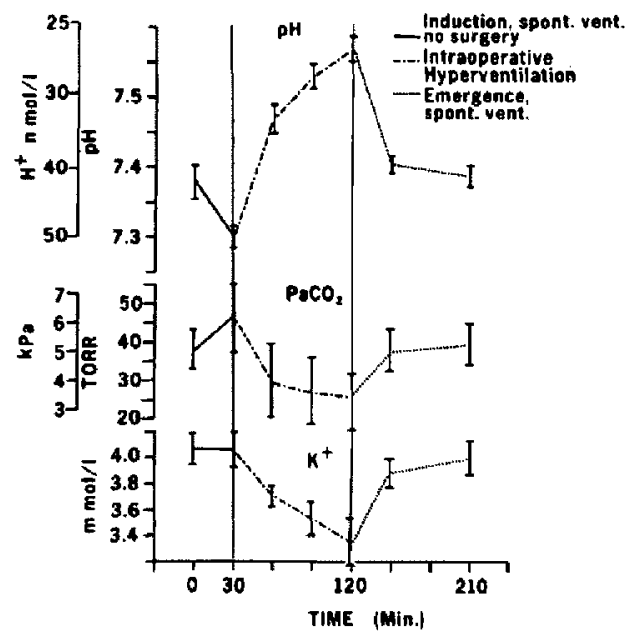

Figure I Changes in blood $\mathrm{H}^{+}(\mathrm{pH}), \mathrm{Paca}_{2}$ and potassium $\left(\mathrm{K}^{+}\right)$levels during the three phases of the experiment.

lasted a further 90 minutes and took place in the recovery room.

Results are expressed as the mean \pm SEM. Significant differences were assessed using Student's $t$ test for paired data, and a $P$ value less than 0.05 is considered significant.

\section{Results}

During the pre-operative phase $\mathrm{pH}$ fell $\left(\mathrm{H}^{+}\right.$increased), as a consequence of a rise in $\mathrm{PaCO}_{2}$ (Figure 1). Both of these changes were significant $(P<0.001)$. This initial respiratory acidosis was interpreted as a summation effect of the narcotic used for premedication, the induction agents and the anaesthetic itself. Serum potassium levels did not change significantly from control.

In the operative phase, as soon as hyperventilation had been initiated, a highly significant increase in $\mathrm{pH}$ (decrease of $\mathrm{H}^{+}$) occurred $(\mathrm{P}<$ 0.001 ), accompanied by a fall in $\mathrm{Pa}_{\mathrm{CO}_{2}}$ to a mean value of $26.0 \pm 1.8$ torr $(3.46 \pm 0.24 \mathrm{kPa})(\mathrm{P}<$ $0.001)$. There was a significant fall in the serum potassium levels ( $P<0.001)$ and at the end of 90 minutes of hyperventilation the mean value was $3.3 \pm 0.04 \mathrm{mmol} / 1$, with the majority of the values (14/17) falling below $3.5 \mathrm{mml} / \mathrm{l}$.

When the serum potassium levels were plotted against the $\mathrm{pH}$ values a linear relationship was observed (Figure 2). The serum potassium fell $0.3 \mathrm{mmol}$ for each 0.1 unit rise in $\mathrm{pH}$ (or $0.03 \mathrm{mmol}$ for each unit decrease of $\mathrm{H}^{+}$).

A mild metabolic acidosis was also observed as

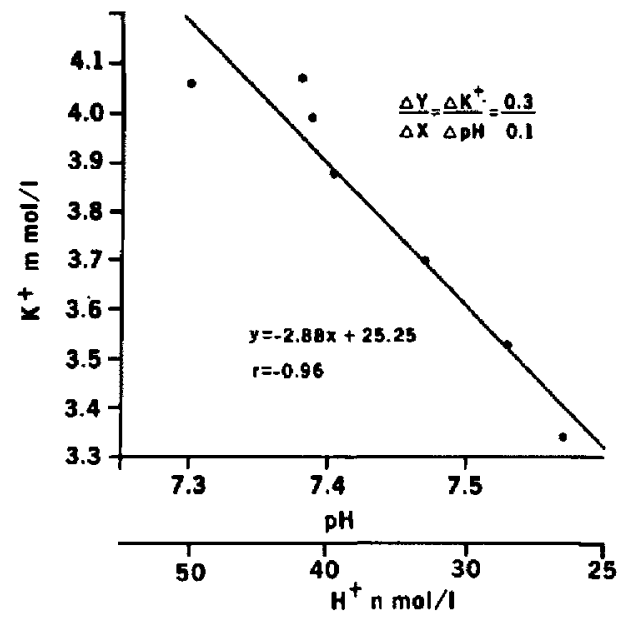

Fugure 2 Blood $\mathrm{H}^{+}(\mathrm{pH})$ values plotted against $\mathrm{K}^{+}$ levels.

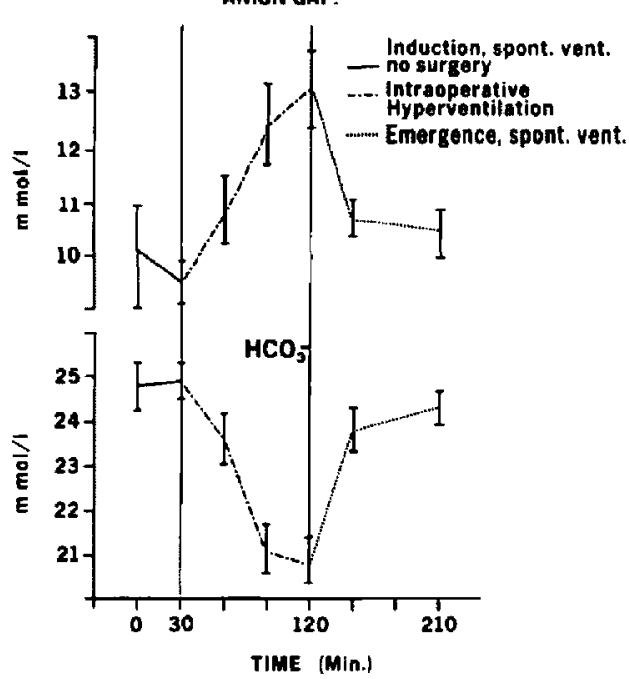

FIGURE 3 Changes in the anion gap (sodium-bicarbonate plus chloride) $\mathrm{mmol} / \mathrm{l}$ and bicarbonate ion (measured total $\mathrm{CO}_{2}$ content, mmol/l) during the three phases of the experiment.

hyperventilation progressed (Figure 3). This was evaluated by interpreting the anion gap as an increase in lactic acid. This acidosis disappeared rapidly during the post-operative phase after discontinuation of the hyperventilation (Figure 1 and 3).

\section{Discussion}

Varying degrees of hypocarbia and hypokalaemia occur with relative ease in the anaes- 
thetized patient as a result of hyperventilation. These changes are probably present in many patients undergoing what is considered ordinary mechanical ventilation during anaesthesia.

The dangers of hypocarbia and hypokalaemia have been objects of extensive study. ${ }^{19-24}$ While we did not observe ill-effects in normal patients, these changes may be extremely significant in patients with cardiac disease or hypertensive patients who are receiving digitalis or diuretics and who may have a pre-existing deficiency of total body potassium. In this group of patients a rapid shift in the serum potassium may lead to the development of hazardous arrhythmias.

The mechanism of the metabolic acidosis in man is subject to some controversy; ${ }^{14}$ however, there seems to be general agreement that the increase in lactic acid is the result of compensatory mechanisms evoked in response to a consistent alkalosis through a disturbance in carbohydrate metabolism. In addition, alkalosis produces a shift to the left of the oxyhaemoglobin dissociation curve, resulting in more difficult unloading of oxygen in the tissues. At the same time decrease in cardiac output would contribute to this acidosis.

\section{SUMmarY}

In summary, one should be aware that hyperventilation and hypokalaemia occur frequently in the operating room under ordinary clinical conditions. An awareness of the rapidity with which these changes occur, and their extent as well as their potential hazards, should cause consideration of more aggressive attempts to maintain normocarbia and to use supplemental potassium during anaesthesia, particularly in patients with cardiac disease.

\section{RÉSUMÉ}

Ce travail est un rappel de la fréquence des situations d'hyperventilation et d'hypokaliémie dans la pratique anesthésique courante. La réalisation de la rapidité avec laquelle surviennent ces changements, de leur importance et de leurs complications possibles, devrait nous rendre plus attentifs au maintien de la normocarbie et à celui de la normokaliémie par l'administration de cet électrolyte en cours d'anesthésie. Tout ceci est encore vrai chez le malade cardiaque et l'hypertendu qui reçoivent de la digitale ou des diurétiques.

\section{ACKNOWLEDGEMENTS}

The authors are grateful for the editorial assistance of Dr. W.H. Noble, and for the assistance of Mr. J.C. Kay in the presentation of the data.

\section{REFERENCES}

I. Anderson, H.N. \& Savane, H. Pattern of biochemical response to acute changes in $\mathrm{Pa}_{\mathrm{CO}_{2}}$. Ann. Surg. 156:752(1962).

2. HaLL, K.D. \& Reeser, F.H. Jr. Serum potassium levels in hyperventilated dogs. Proc. Soc. Exper. Biol. Med. III: 251 (1962).

3. Flemma, R.J. \& Young, W.G. The metabolic effects of mechanical ventilation and respiratory alkalosis in post-operative patients. Surgery $56:(1) 36$ (1964).

4. Eichenholz, A. Respiratory alkalosis. Arch. Int. Med. 116:699 (1965).

5. NuTTAL, F.Z. Serum electrolytes and their relation to acid base balance. Arch. Int. Med. 116:670 (1965).

6. Ferling, R., Heymer, G., \& Satdeler, H.J. Electrolytverschiebungen bei akuter respiratorischer alkalose. Pheumonoalogie 144: 120 (1971).

7. NedY, R. \& BurXZTEIN, S. Influence de l'hyperventilation sur la kalemie. Anaesth. Anal. 23: 4, Paris (1966).

8. Burnell, J.M., Villamil., M.F., Vyeno, B.T., \& SCRIBNER, B.H. The effect in humans of extracelular $\mathrm{pH}$ change on the relationship between serum potassium concentration and intracellular potassium. J. Clin. Invest. 35(9): 935 (1956).

9. Bataglia, F.C., Behrman, R.E., Hellegers, A.E., \& BATTAGLIA, J.D. Intracellular hydrogen ion concentration changes during acute respiratory acidosis and alkalosis. J. of Pediatr. (St. Louis) 66: 737 (1965).

10. LiU, C.T. \& SpurR, G.B. Intra- and extra-cellular potassium concentration of cardiac and skeletal muscle during acute respiratory acid base alterations. Am. J. Med. Sci. Oct. 413-418 (1966).

11. WRight, B.D. \& DiGiovanni, A.J. Respiratory alkalosis, hypokalemia; and repeated ventricular fibrillation associated with mechanical ventilation. Araesth. Anal. (Cleve.) 48-3: 467 (1969).

12. Vasko, K.A., Richard, D.V.M., DeWal.l, R.A., RichaRD, A., \& Riley, A.M. Hypokalemia: physiological abnormalities during cardiopulmonary bypass. Ann. Thorac. Surg. (Boston) 15: 347 (1973).

13. Danhell, H.W. Arrhythmia in hypokalemia N.E.J.M. $284(24): 1385$ (1974).

14. Papadopoulos, C.N. \& Keats, A.S. The metabolic acidosis of hyperventilation, produced by controlled respiration. Anesthesiology 20(2): 156 (1959).

15. SMith, D.C., Barry, J.Q., \& Gol.D, A.J. Respiratory alkalosis and hypokalemia in dogs exposed to simulated high altitude. Am. J. Physiol (Bethesda) 202: 1041 (1962).

16. Scribner, B.H., Frement-Smith, K., \& BurNELL, J.M. The effect of acute respiratory acidosis on the internal equilibrium of potassium. J. Clin. Invest. 34: $1276(1955)$. 
17. Birkenfield, L.W.. Liebman, J., O'Meara, M.P., \& EDELMAN, I.S. Total exchangeable potassium and total body water in edematous patients with cirrhosis of the liver and congestive heart fuilure. J. Clin. Invest. 37:687 (1958).

18. Wong, K.C., Wetstone, D., Martin, W.E., Cheney, F., \& WyTE, S.R. Hypokalemia during anaesthesia: The effects of d-tubocurarine, gallamine, with or without respiratory alkalosis. Anesth. and Analg. (Cleve.) 52:4 (1973).

19. Stuckney, J.L. \& Meyers, F.H. Digitalis toxicity. Am. Heatt J. 85: 501 (1973).

20. Theye, R.A., Milde, J.H., Michelfelder, M.D. Effect of hypocapnia on cardiac output during anaesthe sia. Anesthe siology 27: 779 (1966).
21. Markello, R., Cutter, J.A. \& King, B.D. Hyperventilation studies during nitrous oxide-narcotic-relaxant anaesthesia. Anesthesiology 24: 2 (1963).

22. Danielson, B.G., Grangsjo, G.P., Ulfendahl, E., \& Wolgast, M. Renal function in the dog in acute disturbances of the acid base balance. Acta Anaesth. Scand. 17: 88 (1973).

23. Bliss, H.A., Fishman, W.E., \& Smith, P.H. Effects of alterations of blood $\mathrm{pH}$ on digitalis toxicity. J. Lab. \& Clin. Med. 62-1: 53 (1963).

24. Warren, M.C., Gianelly, R.E., Cutler, S.L., \& Harrison, D.C. Digitalis toxicity. Am. Heart J, $75: 3$ (1968). 